\title{
Twin Deficits Hypothesis as an Indication of Government Failure in Sierra Leone: An Empirical Investigation (1980-2018)
}

\author{
Emerson JACKSON ${ }^{1}{ }^{(0)}$, Mohamed JABBIE² ${ }^{(0)}$
}

\begin{abstract}
This paper examines the assertion of twin deficit hypothesis as an indication of government (policy) failure in Sierra Leone through the utilisation of relevant variables from 1980 - 2018. The paper is considered very important, with its application to the economy of Sierra Leone, which seems to have battled with structural problems, particularly policy failures, as manifested through over-burdened current account and fiscal deficit, which is presently overshadowing efforts of changedregime to make headway with planned developmental goals. Theoretical and empirical literature was reviewed in relation to the twin deficit hypothesis. Empirical outcome using the Fully Modified Ordinary Least Squares (FMOLS) failed to reject the twin deficit hypothesis; an indication that fiscal deficit is partly responsible for the negative current account position in Sierra Leone. Evidence from the outcome is consistent with expectation for a small open economy [Sierra Leone], burdened with failed institutional governance policies in areas connected with unproductive real sector and high lending rates, considered as disincentive to private sector investments. To address the problem, policy recommendations have been proposed, pointing to a boost in real sector activities - this will help facilitate growth and mobilisation drive to improve domestic revenue collection, also channelled through the Treasury Single Account (TSA) for effective monitoring. Conscious efforts should be made to stepup operations that deter corruption, while firming up efforts to to boost exports through competitive business operations.
\end{abstract}

Keywords: Twin deficit hypothesis, government failure, current account balance, fiscal deficit, policy shocks

Jel Code: C12, E62, F32
DOI: $10.26650 / J E P R 658440$

'Doctoral Researcher, Centre of West African Studies, University of Birmingham, Birmingham, United Kingdom; Bank of Sierra Leone, Freetown, Sierra Leone

${ }^{2}$ Financial Analyst, Bank of Sierra Leone, Freetown, Sierra Leone, Freetown, Sierra Leone

ORCID: E.J. 0000-0002-2802-6152;

M.J. 0000-0001-9082-6524

\section{Corresponding author/Sorumlu yazar:} Emerson JACKSON,

Centre of West African Studies, University of Birmingham, Birmingham, United Kingdom

E-mail/E-posta: emersonjackson69@gmail.com

Submitted/Başvuru: 30.10 .2019

Revision Requested/Revizyon Talebi: 27.11.2019

Last Revision Received/Son Revizyon: 06.12.2019

Accepted/Kabul: 20.12.2019

Citation/Atıf: Jackson, E., Jabbie, M. (2020). Twin deficits hypothesis as an indication of government failure in Sierra Leone: An empirical investigation (1980-2018). iktisat Politikası Araştırmaları Dergisi - Journal of Economic Policy Researches, 7(1), 43-68. https://doi.org/10.26650/JEPR658440 


\section{Introduction}

Fiscal discipline and the maintenance of a current account balance are very essential in supporting a well-managed economic system, given their importance for macroeconomic stability and sustained economic growth (Sakyi and Opoku, 2016). Against this background, the 'twin deficit hypothesis' has evolved as a topical concern, underpinned by the implications of fiscal and current account deficits for a healthy economic management. The IMF and many international agencies like the World Bank have been very active in advancing policy prescriptions to minimise the impact of twin deficit at a national scale, which also have passthrough effects on a country's financial well-being, with possible spillages across the global economy (Kılınç, Tunç and Yörükoğlu, 2014; Vyshnyak, 2000). The continued state of imbalances in the current account and fiscal deficit of a country can also result in serious threat to foreign investments, given the doubt it brings to investors and coupled with the risk of repressed growth.

A country's state of economic well-being is closely linked with its fiscal and current account positions. Hence, a deficit in either or both the fiscal and current account can spark serious macroeconomic concerns, simply on account of structural imbalances it creates in meeting basic fiscal obligations to citizens. In this case, a highly indebted country, with huge budget and current account deficits normally faces high risk of not being able to meet its commitments in settling both internal and external debt arrears, in which case, the latter can place the country in a difficult situation of attracting international investors. In many cases, continued fiscal and current account deficits can also result in high risk of capital flight by investors, whose primary intention is to protect their investments (Epaphra, 2017).

The concept of twin deficit, which started in the 1980s is attracting great interest from policy makers, particularly in institutions like central banks and also those in the academia and Think-Tank institutions (see International Growth Centre's commissioned research produced by Sakyi and Opoku, 2016). Twin deficit hypothesis can come about as a result of structural problems inherent in what is referred to as a failed 'governance system', also akin to market failure (Jackson and Jabbie, 2019). Poor real sector activities (connected with a country's real growth) and trade imbalances (that is, excess of import bills over earnings received from export trade) are some of the root causes of the twin deficit curse or syndrome ascribe to a country.

Plethora of theoretical viewpoints have been strongly advanced by policy researchers and those in academia, particularly in relation to differences in fiscal policy stance(s) and that of trade balances - a concept akin to Keynesian doctrine and the Ricardian equivalence hypothesis (Epaphra, 2017). On this note, the Keynesian position asserts that budget deficit 
has a high statistical significance with the current account deficit, through the 'interest and exchange rate' channels (Kearney and Monadjemi, 1990; Haug, 1996), while the Richardian Equivalence hypothesis proposes a contrast view, based on the notion that there is no evidence of causal effects between fiscal and current account deficits (Chowdhury and Sareh, 2007; Olanipekun, 2012; Epaphra, 2017). In short, the position of the Ricardian equivalence hypothesis imply that deficit in the current account is the result of economic agents' reaction on consumption from numerous shocks experienced in an economy.

\subsection{Rationale, Emerging Knowledge Exploration and Structure of the Paper}

The need for further empirical investigation in this area of study has emerged out of the researchers' quest for interrogating concerns around successive regime failures in effectively managing the country's fiscal and current account positions. Most importantly, there is a connection between government failure and market failure (Jackson and Jabbie, 2019; Cunningham, 2011; Winston, 2006), which the authors have contributed towards (See published title: "Understanding market failure in the developing country context", in Springer's Encyclopedia of Sustainable Development: Decent Work and Economic Growth) - in this, the concept of market failure was the focal point of critical discourse, with specific case analysis applied to the Sierra Leone economy. Economic theory asserts that the market fails because of inefficient governance structures and policies that deter a system from working cohesively (see Warburton, 2013). In this regard, the government as the centre piece of developmental agenda normally fails in its duty of care to allocate scarce resources to address basic welfare needs of citizens (Jackson and Jabbie, 2019). This analysis is quite typical of the Sierra Leone economy, battered by both natural and man-made disasters as witnessed in recent times, from the late 1980s and through to the early 2000 millennium specific to this, is a typical situation of government failure in which, successive leaders have injudiciously utilised resources meant to improve welfare condition of citizens.

Studies around the concept of twin deficit are not new in the area of economic research. The emerging priority for knowledge exploration in this study is to utilise variables of interest to explore issues around twin deficit concept, which in this case is seen to be an attribute of poor management and governance resources - this normally translates into market failure on account of the inefficient utilisation of resources. The model estimation for this study would provide an assessment of empirical results, which is hoped will unravel the assertion of twin deficit within the scoping period. It is hoped the proposed recommendations will help tailor policies geared towards efficient utilisation of the country's resources, while at the same time, ensuring investment is spread out to accommodate prospects for economic diversification in a bid to mitigate adverse impacts from shocks as witnessed during crisis periods like Civil War, Ebola epidemic, Global commodity price crash and Mudslide. 


\subsection{Objectives and Hypothesis}

\subsubsection{Objectives of the study}

In view of the focus of this study, the undermentioned objectives are listed below:

(i) Examine trends in fiscal and current account positions of the Sierra Leone economy as a pointers for government failure or not.

(ii) Examine the existence of causal relationship between Fiscal Deficit (FD) and (Current Account Balance CAB) in a bid to advancing policy recommendations for effective governance.

(iii) Empirically examine the implications of the current account balance in view of its association with relevant macroeconomic variables.

\subsubsection{Hypothetical statements}

(i) That unplanned spending by successive regimes is responsible for the country's state of twin deficits crisis

(ii) That causal relationship exists between FD and CAB

(iii) That deficit in both the current account and fiscal positions are responsible for the continued state of sluggish growth in the country.

\subsubsection{Structure of the Paper}

In view of the above introductory discourse in section one, the remaining sections of the paper are divided as follows: (i) Section two provides an Overview of the Government's role in Market Failure and Trends in current account and fiscal deficit positions in Sierra Leone, while section three addresses the literature review, sub-sectioned into 'Theoretical framework and Empirical reviews'. Section four describes variables / data utilised for the study, methodology, and the empirical findings. Section five presents the empirical results and discussion of findings, incorporating highlights on outcomes from Granger Causality, other relevant tests and the FMOLS regression in addressing the objectives and research questions. Finally, section six concludes with a wrap-up of the research and recommendations for policy implementation.

\section{Overview of Market Failure and Failed Governance Trends in Sierra Leone}

\subsection{Role of the Government and Market Failure}

The government is conventionally considered the engine of economic growth and development in a country through efficient allocation of scarce resources. However, this 
speaks to the fact that governments, particularly in developing economies, are mostly seen to engage in manipulating institutions, for example, the legislative arm, perceived as the eyeball for enforcing the efficient allocation of resources (Winston, 2006; Jackson, 2017). Such situations normally pave the way towards a failed market system; this then makes it very difficult for economies to achieve economic efficiency by distorting price mechanism and the allocative distribution of goods and services, which eventually results in huge welfare loss to society (Jackson and Jabbie, 2019; Jackson et al, forthcoming).

With reference to the Sierra Leone economy, it can be said that the lack of efficient allocation of resources went unchecked for decades, due to the regime's manipulation of the political landscape into becoming a unilateral system, capable of masterminding key institutions like the legislative arm in promoting policies geared towards selfish enrichment at an unsustainable rate. The existence of a corrupt system of governance witnessed in Sierra Leone since the 1980s gave way to public officials in key ministries and parastatals to become patronisers of failed government policies, despite curative interventions (e.g. structural adjustment programs) devised by international institutions like the World Bank and IMF to reverse the country to a steady-state ${ }^{1}$ governance, modelled on the doctrine of competitive market economics (Jackson and Jabbie, 2019). The existence of failed governance plagued the country with potential signs for market failure, as highlighted in world economic outlook results (World Bank, 2018; United Nations, 2011) - epitomized by high levels of corruption, deep-seated fiscal indiscipline and systemic current account deficit - also, attributable to lack of efficient structures in managing resources, particularly natural wealth for the good of present and future generations in the economy (Tarawallie, 2014).

In view of Messner and Meyer-Stamer's (1992) research output, an efficient market system requires strong government and transparent institutions to allow economic agents to act in the best interest of a nation. Over the years, Sierra Leone has been plagued by the ills of all of the identified forms of market failures as highlighted here - 'Externalities, Asymmetric information, Public goods, Natural monopoly, Imperfect competition and Business cycle' (see Jackson et al, forthcoming; Jackson and Jabbie, 2019; Thomas, 2018; Cunningham, 2011; Winston, 2006). There is a need to ensure the curse of twin deficit hypothesis is blighted from the country's face; this can be achieved through the dedication and the enabling of the political-will of leaders, whose focus is to institute systems that eradicate leakages, while also ensuring resources are mobilized to minimise excessive fiscal and current account deficits. In view of this, one would acknowledge a regime change

\footnotetext{
1 Steady state concept in Economics is epitomized by a constant stock of physical wealth and population size. Despite issues around stagnant growth potential in a steady-state economy, it is characterised by equilibria, with great potential for growth in the event of wealth being utilised efficiently by those in authority.
} 
approach that instituted full operation of the Treasury Single Account (TSA) in a bid to ensure expenditures are centralised through a well-managed system, while also pursuing conscious efforts to improve the drive towards raising revenues in addressing planned fiscal operations and the promotion of economic diversification.

\subsection{Trends in Current Account and Fiscal Position in Sierra Leone}

Sierra Leone, a naturally endowed country with a plethora of renewable and nonrenewable wealth continues to be in the spotlight, particularly in relation to its resource curse syndrome, which is attributable to poor governance and mismanagement of her resources (Jackson and Jabbie, 2019; Jackson, 2016; Jones, 2014). In addition to this, the continued state of weak real sector activities, coupled with trade imbalances have made it such that the current account position is continually placed in the spotlight of deficit (Tarawalie, 2014). In view of the destructive legacy of civil crisis experienced in the country during the late 1980s, and coupled with the blatant level of corruption demonstrated by some public servants (Jackson, 2017), the economy is now left to thrive on a weak pathway of recovery as manifested in the regime-change drive to address fiscal indiscipline, which is still a challenge in attracting potential investors. The lack of foresight of state actors in key institutions to diversify the economy during the boom time of Iron Ore exploration resulted in a situation whereby the emergence of twin shocks (Ebola epidemic and commodity price slump) placed the economy in a plummeted state of decline; a situation that is still being battled with as witnessed in the sluggish recovery of both the fiscal and current accounts.

The continued over-reliance of (successive) governments' appetite to borrowing in a bid to finance fiscal operations, can to a greater extent, be blamed for the weak state of the current account position, and hence its ability to support investment operations to diversify the economy. This is exacerbated by the failure to efficiently manage resources, which results in accumulated debt burden, distortion of market equilibrium and ultimately, welfare loss to society. Figure 1 below, which captures the trend in fiscal and current account reflects that for the most part, the two variables moved in the same direction, indicating a strong degree of correlation. Periods of high current account deficit are accompanied by fiscal deficit, which became more glaring from the year 2000, with notable periods around 2010, 2011, 2013 and 2015. It can be discerned from Figure 1 that in the periods $1990-1995$, fiscal deficit was very low, largely on account of fiscal discipline, modelled on the implementation of Structural Adjustment Programme (SAP) in the 1990s - this era witnessed a reduction in unidentified ghost and daily-waged workers' pay-roll vouchers of up to $50 \%$ (Korsu, 2014). These periods were followed by low current account deficits. The story changed from 1996 - 2002 on account of the civil war, which induced curtailment in revenue and an overburdened government expenditure. This was also reflected in the current account 
position, albeit modestly, since the civil war impaired the productive capacity of the economy, thus reducing exports and the resulting revenue it generated for managing the economy.

Outturns in fiscal operations after the war continued to result in deficit as the reigning regime was presumable engaged in rehabilitation and reconstruction of the defunct state. However, there were also inherent fiscal slippages, resulting from gross fiscal indiscipline, which partly explains the case of failed government policies. The current state of twin deficits in the economy could be attributed to the inherited legacy of fiscal indiscipline, with the government's appetite towards high interest borrowing from external sources - the lack of diversification efforts in the real sector is also to be blamed for the high import bills - this also has implications, given the risks of not adhering to international requirements on 3-months of import cover. There was a notable improvement in the fiscal and current account deficit in 2012 and 2013, driven mainly by iron-ore related export receipts, which bolstered government revenue, thereby solidifying the country's external position and a record economic growth rate of 15.2 percent and 20.7 percent in 2012 and 2013 respectively. However, due to the 'mono-sector economy'" tendency of governance, gains obtained in 2012 and 2013 were short-lived, as the country was hard-hit by the twin shocks of the Ebola Epidemic and the Iron Ore price slump in 2015, which worsened the fiscal and current account, and also a contraction of the economy by 20.5 percent.

Figure 1: Trends in Fiscal and Current Account Deficits

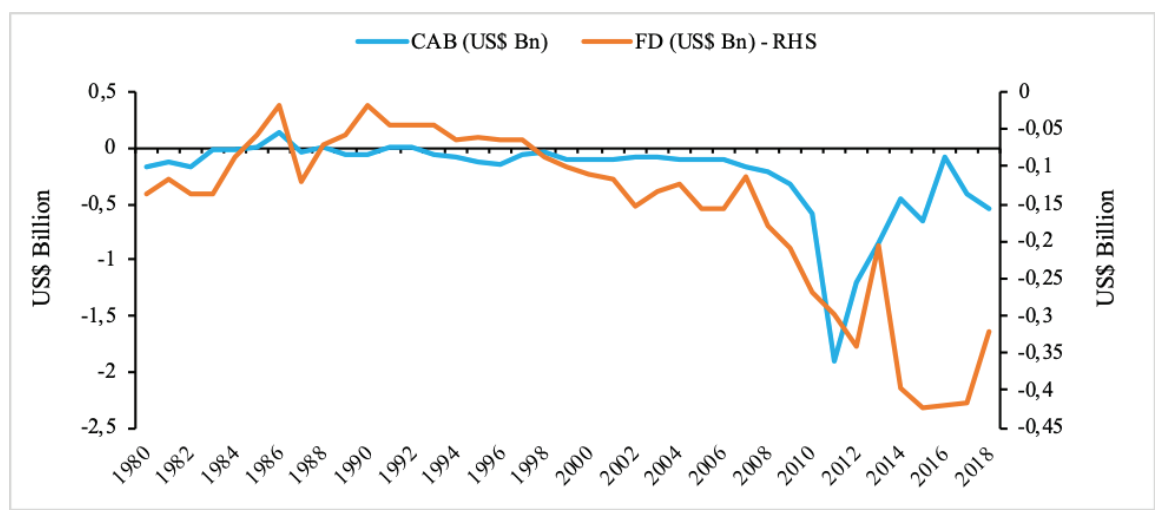

Source: WEO, MEFP and authors

\footnotetext{
2 This is epitomized by a system that lacks vision in addressing diversification of the economy from gained obtained through resource boom. There seems to have been a lack of vision between the period 2012-13 to judiciously invest proceeds from Iron Ore sales in diversifying the economy - while gallivanting on wasteful spending, there emerged the twin shock (Ebola and commodity price slump) around 2014-15 and later followed by the Mudslide in 2017, which eventually battered the economy into depression.
} 


\section{Literature Review}

\subsection{Theoretical Review and Framework}

The original idea of twin deficit hypothesis emerged around 1980-90, in explanation of current account deficit experienced in the United States of America (Darrat, 1988; Abell, 1990; Sakyi and Opoku, 2016; Epaphra, 2017). This was a period characterised by excessive fiscal deficit, which resulted in the depreciation of the United States dollar, with an ultimate expansion in the current account deficit during the reign of President Ronald Reagan.

The twin deficit hypothesis is derived from the National Income Identity (NII), which for an open economy is stated below in equation 1:

$$
\mathrm{Y}=\mathrm{C}+\mathrm{I}+\mathrm{G}+(\mathrm{X}-\mathrm{M})
$$

Where: $\mathrm{Y}$ is gross domestic product, $\mathrm{C}$ is private / household consumption expenditure, I is real investment expenditure in the economy, $\mathrm{G}$ is government expenditure, $\mathrm{X}$ is export goods and services and $\mathrm{M}$ is import goods and services.

The current account balance $(\mathrm{CAB})$ is defined as:

$$
\mathrm{CAB}=\mathrm{NX}+\mathrm{NI}
$$

Where NI is net income, which is a composite of both net primary income (net factor income - compensations of employees, investment income, etc.) and net secondary income (current transfers from nonresidents minus transfers remitted abroad from residents). NX is net export, which is the difference between exports of goods and services and imports of goods and services, which is $(\mathrm{X}-\mathrm{M})$.

The current account deficit is an indicator of external imbalance, which depicts the magnitude and direction of international borrowing and lending. If a country's current account is in surplus, it means exports outweigh imports, implying it is a net lender to foreigners. On the contrary, if the current account is in deficit, then imports outweigh exports, reflecting that it is a net borrower to foreigners. Such borrowing may be done by the government or the private sector. A country with a current account deficit has its residents giving out liabilities that are bought by non-residents.

In line with the national income identity, national saving $(\mathrm{S})$ in the open economy equals:

$$
\mathrm{S}=\mathrm{Y}-\mathrm{C}-\mathrm{G}+\mathrm{CAB}
$$

Where $\mathrm{Y}-\mathrm{C}-\mathrm{G}=\mathrm{I}$ and $\mathrm{I}$ is investment. 
Therefore, in an open economy the national saving identity is expressed as:

$$
\mathrm{S}=\mathrm{I}+\mathrm{CAB}
$$

However, savings in the economy are done by both private individuals and the government, therefore national saving is decomposed as:

$$
\mathrm{S}=\mathrm{S}^{\mathrm{p}}+\mathrm{S}^{\mathrm{g}}
$$

Where $\mathrm{S}^{\mathrm{p}}$ is the portion of an individual's income that is saved after deducting taxes and consumption expenditure, expressed as:

$$
\mathrm{S}^{\mathrm{p}}=\mathrm{Y}-\mathrm{T}-\mathrm{C}
$$

Where, $\mathrm{T}$ is taxes paid to the government.

Government saving on the other hand is the difference between government tax revenue (T) and expenditures on goods and services (G), and government transfers (Tr). This is expressed mathematically as follows:

$$
\mathrm{S}^{\mathrm{g}}=\mathrm{T}-\mathrm{G}-\mathrm{Tr}
$$

In line with the definition of national saving, equation $6 \& 7$ are substituted into equation 4, which gives:

$$
\mathrm{S}=\mathrm{S}^{\mathrm{p}}+\mathrm{S}^{\mathrm{g}}=(\mathrm{Y}-\mathrm{T}-\mathrm{C})+(\mathrm{T}-\mathrm{G}-\mathrm{Tr})=\mathrm{I}+\mathrm{CAB}
$$

Equation (8) is expressed in the form below to capture the effects of government saving decisions.

$$
\mathrm{S}^{\mathrm{p}}=\mathrm{I}+\mathrm{CAB}-\mathrm{S}^{\mathrm{g}}=\mathrm{I}+\mathrm{CAB}-(\mathrm{T}-\mathrm{G}-\mathrm{Tr})
$$

Rearranging (9) and expressing it in terms of the current account yields:

$$
\mathrm{CAB}=\mathrm{S}^{\mathrm{p}}-\mathrm{I}-(\mathrm{G}+\mathrm{Tr}-\mathrm{T})
$$

Equation (10) shows that the current account balance is a function of the savings deficit $\left(\mathrm{S}^{\mathrm{p}}-\mathrm{I}\right)$ and the fiscal deficit $(-\mathrm{G}-\mathrm{Tr}+\mathrm{T})$.

Theoretically, two possible scenarios can be deduced from equation (10); firstly, with the assumption that private savings $\left(\mathrm{S}^{\mathrm{p}}\right)$ and investment (I) are constant over time, variations in the fiscal position $(-\mathrm{G}-\operatorname{Tr}+\mathrm{T})$ have the tendency of triggering fluctuations in the current account, which means the existence of a twin deficit hypothesis (see Kim and Roubini, 2008 and Gavallo, 2005) - as the fiscal deficit and current account deficit are correlated. The second theoretical inference is rooted in the Ricardian Equivalence Hypothesis, which assumes that changes in fiscal operations will be perfectly balanced by changes in the 
difference between savings and investment. When this happens, the twin deficit hypothesis will not hold, implying that fluctuations in the fiscal balance are uncorrelated with the current account deficit (Suresh adnd Tiwari, 2014; Barro, 1989)

The concept of twin deficit hypothesis as proposed by the Keynesians indicates that the incidence of fiscal deficit resulting from the increase government spending over its revenue generated, normally results in a current account deficit (Sakyi and Opoku, 2016). This can occur via three channels: (i) the increase in interest rate, which crowds out private sector investment; (ii) the exchange rate; and (iii) the extent of capital inflows, resulting from the increase in domestic interest rate (see Flemming, 1962; Mundell, 1963; Dudley and Mckelvey, 2004).

\subsection{Empirical Literature}

This section of the paper addresses empirical research undertakings in the topical area of twin deficit hypothesis. In view of the early development of the twin deficit hypothesis, which started revealing itself around the 1980s to 1990s on account of structural issues in the USA, Abell (1990) eventually made use of quarterly data for the period 1979 to 1985 by utilising the vector autoregressive (VAR) model. In this, he proved that fiscal deficits influenced current account deficits in the United States.

Vyshnyak (2000), empirically investigated a study on twin deficit hypothesis using Ukrainian data. The outcome from the study shows that transmission mechanism between the two deficits is due to exchange rate concerns. Results based on statistical tests proved that government budget deficit and current account deficit are cointegrated, while the Granger causality test indicates that the past value of government budget deficit is a contributing factor in explaining the current account deficit. In view of the equation: $\mathrm{CA}=$ $\mathrm{S}^{\mathrm{pr}}-\mathrm{I}-\mathrm{BD}$, the result shows that the relationship between private savings and investment is more or less stable over time, which meant that changes in the budget deficit are transmitted to the current account - a result which is compatible with studies conducted for most developing economies. In summary, the study proved that the twin deficit relationship may cease to exist through implementation of government's market-led reforms that is geared towards improving the business environment and investment activities.

Lau and Baharumshah (2006) made use of panel data for the period 1980 to 2001 from nine South East Asian Central Banks (SEACEN) countries; using dynamic OLS (DOLS) panel VAR methodology, the authors were able to explore the assertion of twin deficit hypothesis. In this, they found out that an increase in fiscal deficits causes current account deficits to increase, thereby proving the claim of the twin deficit hypothesis. 
To explore the assertion of twin deficit hypothesis further, Uz (2010) carried out a study to address the major determinants of the current account in Turkey, which examined the long-run and short-run impact of the exchange rate, private and public savings on the current account balance. The use of bounds testing using the Autoregressive Distributed Lag (ARDL) approach to cointegration indicate a strong support for cointegration between current account balance and the selected variables. The exchange rate revealed the strongest impact on the current account, but with signs of varying differences in the short and long-run period. Finally, the outcome of the study supports the presence of twin deficit assertion in Turkey, but with a rather weak relationship than expected.

The closest study on twin deficit in Sierra Leone was investigated by Tarawalie (2014). In his study, he examined short and long run relationships between budget and current account deficits in Sierra Leone by applying the bounds test approach and Toda Yamamoto (1995) causality analysis using annual data for the period 1980-2012. Results from the study revealed budget deficit, real GDP and political instability (proxy by war dummy) to have a positive impact on current account deficit in the long run. Short run estimates show that budget deficit and war dummy were the most significant influence on the current account deficit in Sierra Leone. In furtherance, Granger Causality tests reveal that uni-directional causality exists from budget deficit to current account balance and from current account balance to real GDP, with no feedback effect. However, there was no causality existing between current account balance and the other explanatory variables. Key take home from the study indicates that policy measures to reduce budget deficit by authorities should be targeted in a bid to reduce trade deficit, which is thought to be achieved through sound and prudent fiscal policies aimed at providing incentives to increase revenue mobilization and rationalization of government expenditures.

Bangura et al. (2016) investigated key macroeconomic determinants of the budget deficit in Sierra Leone by utilising empirical analysis from Vector error correction model (VECM) and variance decomposition techniques, with annualized time series data spanning 1980 to 2014. In this, the impact of real GDP growth, inflation, interest rate, exchange rate and government investment on budget deficit were determined. Long run results from the study show that, real GDP, interest rate and exchange rate have a negative impact on budget deficit, while on the other hand, inflation and government investment produced a positive effect. Analysis from the short run results also attest that real GDP, interest rates and investment are the key determinants of budget deficit during the periods under investigation. Own shock (using Variance Decomposition Analysis) with respect to budget deficit exhibits the largest component variation, followed by government investment, inflation and real GDP. The policy implications attest to the fact that budget deficit in Sierra Leone is basically a macroeconomic problem and is due to imbalances - these include high inflation, low levels 
of economic activities, high interest rate and high government investment. There is a caveat here about the use of the phrase 'high government investment', which in this case is perceived as ambiguous. Drawing on pluralist economics thinking, it seem very obvious for a critical thinker to deconstruct the semantics of 'high government investment' expression by way of hermeneutic examination or otherwise, empirically to be more precise (Jackson, forthcoming) - this is considered a grey area for cross examination in relation to disinterring tangible measurement of value-for-money to tax-payers, particularly in the area of economic diversification and sustained growth in the domestic economy.

There is a contention at play here, more so in terms of addressing the dynamics between fiscal deficit and current account balance as key determinants of twin deficits in the Sierra Leone economy, which to a greater extent can be attributed to government failure. As addressed by Tarawalie (2014), the influence of dummy variable speaks to the fact that weaknesses in government policies to judiciously utilise resources is an attributable factor for the decade of civil crisis which the country experienced in the late 1980s to the early part of the year 2000. As emphasised by Jackson and Jabbie (2019), government failure is considered an engine for market failure, and the lack of diversification effort as witnessed over the years, exposed the country's vulnerability to shocks as evidenced in the wake of the twin-shock (Iron Ore price slump and Ebola) that erupted in mid-2014 to the latter part of 2015. As noted by Zayid (2018) in the economic outlook for Africa, Sierra Leone's prospect for growth is still challenged, owing to its high current account deficit, despite debt consolidation efforts set in place by the incumbent regime in 2018 to offset debt arrears and return the country to long-run stability. Similarly, findings from Bangura et al (2016) also attest to the fact that weaknesses in macroeconomic indicators are part of government jurisdiction, which seem to have lapsed for a long period of time, hence making it very apparent about failure on the part of the government to utilize available resources to champion national development efforts. Failure to diversify the economy (through productive investment in real sector activities), particularly during the boom time of Iron Ore exploration is a typical case of government failure, which ultimately feeds into market failure, in a broader sense of the word.

To digress further into the (empirical) literature on Fiscal deficit and current account balance as elements of twin deficit, Conteh (2016) also outlined in his thesis weaknesses in budget credibility in Sierra Leone, which has made it very difficult for government budget to be utilised as a means for planning and efficiently allocating the nation's resources. The study utilizes a methodological mix approach; this includes secondary and qualitative data sought around the period 2010-2014 from staff in key ministries. The findings acknowledged a lack of credibility in the government budget on account of significant variances between the budget and actual outcomes, and also the inefficient role of the legislature, which is 
attributable to 'government failure - also akin to market failure'. The findings emphasise a complete re-write of the budget law, with recruitment of highly qualified and experienced staff to strengthen the legislative budgetary function, considered very important in promoting positive social and economic development drive for the 'economy as a whole.

Sakyi and Opoku (2016) carried out an empirical investigation to explore the issue of whether long-run relationship exists between fiscal and current account deficits, which follows the tenets of the twin deficits hypothesis. In order to prove their case on the asserted debate, the study was restricted to the case of Ghana over the period 1960-2012, by utilising the cointegration techniques with allowance for structural break. The outcome reveals that fiscal deficit improves the current account deficit, which is a proof of the assertion of twin divergence hypothesis, adding to the fact that the twin deficit hypothesis should not necessarily gain universal acceptability over the twin divergence counterpart.

Epaphra (2017) examines the relationship between current account and government budget deficits in Tanzania. In this, he tested the validity of the twin deficit hypothesis using annual time series data for the period 1966-2015. The empirical tests from the study fail to reject the twin deficit hypothesis, indicating that rising budget deficits put more strain on the current account deficits in Tanzania. The use of a Vector Error Correction Model supports the conventional theory of a positive relationship between fiscal and external balances, with a relatively high speed of adjustment toward the equilibrium position. The outcome seems quite consistent with a small open economy like Tanzania and to address the anomaly, it was suggested that some measures like a 'reduction in non-development expenditure, enhancement of domestic revenue collection and actively fight corruption and tax evasion' should be adopted. In his final conclusion, the author also suggested that the government should target export oriented firms and encourage an import substitution industry through the establishment of favorable business environment.

In view of the above highlights (from the theoretical framework as well as from the empirical literature) of pursued venture by researchers from different regions in the world, the authors are very keen to utilise relevant time series data to explore the assertion of twin deficit in the context of Sierra Leone, which seems to have been battered by successive failures attributable to poor governance, as revealed in both the fiscal and current account positions.

\section{Description of Data and Methodology}

\subsection{Description of Data and Sources}

Annual time series data at use for this study ranged from 1980 to 2018, and include the following variables: 
Current Account Balance: This variable was sourced from the world economic outlook (WEO) database; it is treated as part of the Balance of Payment computation and it addresses three key areas like 'Merchandise, Services and Income and Investment position of the country', and each of these are computed on the basis of balances emanating from debit and credit activities within a year. When the import bill exceeds earnings from export proceeds, the overall balance is said to be a deficit to the country, which is normally financed through government debt sourced from domestic and international positions. This gives a real attestation of government's efforts in ensuring that resources are judiciously used so as to reduce the burden on deficit financing, normally manifested on the central bank's balance sheet.

Fiscal Deficit: This variable was sourced from various IMF memorandums of economic and financial policies (MEFP) and it deals with debt obligations of the government and its efforts to appropriate resources in the best way for utilisation in a country. This provides an outlook of shortfall in government income in comparison with its expenditure. In short, fiscal deficit implies higher spending by government authorities over revenues received during the financial year. Receipt based on GDP includes taxes and other forms of revenue, but excludes borrowed money utilised to cover up shortfall in revenue.

Interest Rate [Bank Lending Rate]: this was sourced from the BSL data-warehouse website. It is basically a form of rental or leasing charge, levied on customers intending to borrow for the purpose of withdrawing cash or indirectly, to settle transactions for the use of an asset like a car or construction of a building. In developed and other emerging economies, rates set by commercial banks or financial institutions are based around the Monetary Policy Rate [MPR] announced by the central bank. In this case, rates can vary depending on the risk classification of a borrower. In this vein, a low risk customer can be set a much lower or negotiable rate(s), which is publicly announced by lending institutions. In Sierra Leone, lending rates are mostly set above the MPR, which is a disincentive to investment opportunities for private investment, and a possible explanation for market failure. In most cases, because of the low level of real sector activities and structural problems inherent in the economy, there is a high tendency for non-repayment to occur, which is a root cause of financial instability.

Real Gross Domestic Product [RGDP]: This is a very important economic variable used to determine the health of a nation's economic activities (data at use for this variable is sourced from the IMF world economic outlook database). In short, it is the totality of all goods and services produced over a specific period of time. In Sierra Leone, RGDP is computed annually. The Ebola epidemic and decline in the price of Iron Ore have contributed immensely to weaknesses in real sector activities and recovery has been rather weak or immediately sustained. 
Dummy Shock Variable: This variable was created with the intention of accommodating the real impact of shocks to the Sierra Leone economy within the study period. Such shock includes the incidence of Civil Unrest, Commodity price disturbance during the year 201415 and the Ebola Epidemic that struck around 2014-16. The year 2014 was seen as a difficult time for the economy, given the occurrence of twin shocks (Ebola and Commodity Price fluctuation). Hence, to address its impact in view of the knowledge exploration, the inclusion of a dummy shock variable (indicated by the value of 1) serves as a means for ascertaining the degree of government failure in relation to disturbances that cropped up as a result of man-made occurrences as in the case with the civil crisis and natural disasters, attributable to the Ebola Epidemic and Mudslide crisis.

\subsection{Methodology}

\subsubsection{Model Specification}

With reference to the expression in equation 10, we hereby provide a simplified equation, which explains the relationship between CA and its determinants in order to confirm empirically the assertion of twin deficit in Sierra Leone, which on extension is attributed to structural problems inherent in failed regimes since the 1980s.

$$
\begin{aligned}
& C A=f(F D, R, Y) \\
& C A_{t}=\alpha_{0}+\alpha_{1} F D_{t}+\alpha_{2} R_{t}+\alpha_{3} Y_{t}+\alpha_{t} D u m_{s h}+\varepsilon_{t}
\end{aligned}
$$

Where: $C A_{t}$ is Current Account, $Y_{t}$ is RGDP, $R_{t}$ is interest rate, $F D_{t}$ is budget or fiscal deficit and Dum $s h$ is shocks to the economy, which in this case include the Civil Crisis in the late 1980s, the Ebola Epidemic and Commodity Price slump in Iron Ore.

\subsubsection{Estimation Technique}

Given that Sierra Leone as a country has undergone several structural changes, this study focuses attention on assessing the assertion of the twin deficit hypothesis by firstly taking into account structural breaks that may have taken place during one or more periods. On this note, the paper commenced the empirical process with unit root test, and specifically the usual Augmented Dickey Fuller (ADF) test to determine variables' stationarity at either level or difference. However, according to Maddala \& Kim (1998), the unit root test assumes implicitly that the deterministic trend is specified accurately, failing to consider that events like policy changes, war and commodity price shocks among others can affect the performance of models with constant coefficients. To control this, the Zivot-Andrews unit root tests were utilised in order to capture the impact of structural breaks in determining the order of integration of the variables. In consonant with this, the Gregory-Hansen structural 
break cointegration test was employed to determine whether there is a long run relationship between the variables. Establishing a cointgrating relationship prompted the use of the cointegration regression approach, specifically utilising the Fully-Modified Ordinary Least Squares (FMOLS) model to confirm whether the twin deficit hypothesis holds for Sierra Leone.

\section{Empirical Results and Discussion of Findings}

This section presents the outcome from the estimation, which involves various tests as already mentioned (Unit Root, Granger Causality, Fully-Modified Ordinary Least Squares [FMOLS] Regression Analysis, etc.) and discussion of results. For this study, we have made use of both EVIEWS and STATA applications to enable effective presentation of outcomes and also ensuring the conclusion is well in support of theoretical underpinnings, which also affirm actions for sound policy recommendations.

\section{Unit Root Tests}

In order to avoid the problem of spurious regression resulting from failing to ascertain stationarity, unit root tests were undertaken to determine the order of integration of the observed indicators. On this note, the Augmented Dickey Fuller test was used because of its capability to handle complex models, while at the same time controlling for serial correlation by approximating structure of the errors. In addition, the Zivot-Andrews unit root test was employed in order to capture the effect of structural breaks in the unit root tests.

\section{Augmented Dickey Fuller Unit Root Test}

The Augmented Dickey Fuller (ADF) unit root test as indicated in Table 1 was used to determine the level of stationarity of the variables without checking for structural breaks. The results indicated that all the variables were non-stationary at all levels. However, after differencing, stationarity was achieved at one percent conventional level of significance, reflecting that the null hypothesis of the variables having unit root was rejected.

Table 1: Augmented Dickey Fuller (ADF) Test: Schwarz Bayesian Criterion (SBC)

\begin{tabular}{lll}
\hline Variable & Levels (I(0)) & First Difference (I(1)) \\
\hline CAB & -2.413438 & $-6.994782^{* * *}$ \\
FD & -1.009521 & $-7.975730^{* * *}$ \\
LR & -2.317225 & $-4.873453^{* * *}$ \\
RGDP & -0.111395 & $-4.346163^{* * *}$ \\
\hline
\end{tabular}

Note: $* * *=1 \%$ significance 


\section{Zivot-Andrews Structural Break Unit Root Test}

The Zivot-Andrews structural break unit root test (see Table 2) was used to ascertain the effect of breaks in checking for stationarity in the variables and also to complement the results from the Augmented Dickey Fuller unit root test - which may have produced spurious results in the presence of structural breaks. The break years were endogenously determined. The results as presented in the table below shows that, by allowing for break in trends, it was deduced that the variables were non-stationary at levels, but became stationary after first differencing. This implies that by allowing for structural breaks, the variables are all integrated of order one, which further confirms results from the ADF test.

Table 2: Zivot-Andrews Structural Break Unit Root Test - Allowing for break in trend

\begin{tabular}{lllll}
\hline Variable & Levels (I(0)) & Break Year & First Difference (I(1)) & Break Year \\
CAB & -3.237 & 1999 & $-7.063 * * *$ & 2012 \\
FD & -4.344 & 1997 & $-4.932 * * *$ & 2012 \\
LR & -4.063 & 1991 & $-5.000 * * *$ & 1995 \\
RGDP & -4.106 & 2001 & $-4.622 * *$ & 2012 \\
\hline
\end{tabular}

Source: EVIEWS Output

Note: $* * *=1 \%$ and $* *=5 \%$ significance

\section{Correlation and Causality}

The correlation matrix as shown in Appendix $1 \mathrm{~A}$ reveals a strong positive relationship between fiscal deficit and current account deficit. However, correlation does not imply causation, hence the utilization of the Granger causality test (see Appendix 1B), which indicated a unidirectional causation. Running from fiscal deficit to current account deficit was an attestation of causation. This was attained at a ten percent level of significance, indicating a weak causation. Moreover, both the fiscal deficits showed a somewhat strong negative relationship with economic growth, as proxied by the real GDP. This was corroborated by the causality test that manifested a unidirectional causation from fiscal deficit and current account deficit to economic growth, which were significant at the five and one percent levels, respectively.

\section{Cointegration Tests}

Checking for cointegration is primarily to determine the existence of a long-run relationship between two or more variables. Ascertaining this relationship informs policy makers of long-run correlation and trajectory of two or more indicators, which helps in formulating appropriate policies. On this note, the Gregory-Hansen test was preferred over the other conventional cointegration tests, such as the Engel-Granger, Johansen and ARDL test, because it accounts for structural breaks in the cointegration equation. 


\section{Gregory-Hansen Cointegration}

The Gregory-Hansen cointegration (see Table 3) is a modification of the residual based test by Engel and Granger (1987) and Phillips and Ouliaris (1990), which allows for structural breaks in the cointegration equation, particularly a regime shift that may have taken place in one or more periods in the determination of a long run relationship among a set of variables. It tests the null hypothesis of no cointegration against the alternative of a cointegration with the possibility of one time structural break; determined within the model.

The results shows that the modified $\mathrm{ADF}$ and $\mathrm{Z}_{\mathrm{t}}$ test statistics rejected the null hypothesis of no cointegration in the models with change in regime, and regime shift and trend, with break dates of 2009 respectively. This was reflected in the statistical significance of both models, at the one percent level. However, the other models failed to reject the null hypothesis of no cointegration at all conventional levels. Furthermore, the $Z_{a}$ test statistic failed to reject the null hypothesis of no cointegration for all models, and, as explained by Gregory-Hansen (1996), this is because the statistic is biased in the direction of the null when there is no serial correlation. Therefore, the results indicate that there is a cointegrating relationship between fiscal deficit, current account deficit, lending rate and the real GDP of Sierra Leone, with a change in regime as well as a change in regime and trend. This is captured in the table below:

\subsection{Gregory-Hansen Test for Cointegration with Regime Shifts}

Table 3: Gregory-Hansen Structural Break Cointegration Test - AIC

\begin{tabular}{|c|c|c|c|c|c|}
\hline \multirow[t]{2}{*}{ Model $(\Delta$ in Level $)$} & \multirow[t]{2}{*}{ Test Statistic } & \multirow[t]{2}{*}{ Break Date } & \multicolumn{3}{|c|}{ Asymptotic Critical Values } \\
\hline & & & $1 \%$ & $5 \%$ & $10 \%$ \\
\hline$A D F$ & -5.02 & 2007 & -5.77 & -5.28 & -5.02 \\
\hline$Z t$ & -4.97 & 2012 & -5.77 & -5.28 & -5.02 \\
\hline$Z a$ & -30.93 & 2012 & -63.64 & -53.58 & -48.65 \\
\hline \multirow[t]{2}{*}{ Model $(\Delta$ in Level \& Trend) } & Test Statistic & Break Date & \multicolumn{3}{|c|}{ Asymptotic Critical Values } \\
\hline & & & $1 \%$ & $5 \%$ & $10 \%$ \\
\hline$A D F$ & -5.04 & 2007 & -6.05 & -5.57 & -5.33 \\
\hline$Z t$ & -4.87 & 2012 & -6.05 & -5.57 & -5.33 \\
\hline$Z a$ & -30.01 & 2012 & -70.27 & -59.76 & -54.94 \\
\hline \multirow{2}{*}{ Model $(\Delta$ in Regime $)$} & Test Statistic & Break Date & \multicolumn{3}{|c|}{ Asymptotic Critical Values } \\
\hline & & & $1 \%$ & $5 \%$ & $10 \%$ \\
\hline$A D F$ & -9.07 & 2009 & -6.51 & -6.00 & -5.75 \\
\hline$Z t$ & -8.93 & 2009 & -6.51 & -6.00 & -5.75 \\
\hline$Z a$ & -52.79 & 2009 & -80.15 & -68.94 & -63.42 \\
\hline \multirow[t]{2}{*}{ Model $(\Delta$ in Regime \& Trend) } & Test Statistic & Break Date & \multicolumn{3}{|c|}{ Asymptotic Critical Values } \\
\hline & & & $1 \%$ & $5 \%$ & $10 \%$ \\
\hline$A D F$ & -11.95 & 2009 & -6.89 & -6.32 & -6.16 \\
\hline$Z t$ & -11.79 & 2009 & -6.89 & -6.32 & -6.16 \\
\hline$Z a$ & -60.12 & 2009 & -90.84 & -78.87 & -72.75 \\
\hline
\end{tabular}

Source: EVIEWS Output 
Endorsing cointegration amongst the variables does not mean that the twin deficit hypothesis holds for Sierra Leone. Confirming the twin deficit is largely a function of the direction of the relation and the statistical significance of the results.

\subsection{Cointegration Regression}

The attainment of stationarity as well as cointegration among the variables, stimulated the estimation of the long run model to determine the twin deficit hypothesis. To achieve this, the Fully Modified Ordinary Least Squares (FMOLS) estimation technique as shown in Table 4 was used. The FMOLS estimator, as developed by Phillips and Hansen (1990), possesses parametric efficiency in small samples and controls for serial correlation and endogeneity in the explanatory variables (Sakyi and Opoku, 2016).

Table 4: Fully Modified Ordinary Least Square (FMOLS)

\begin{tabular}{lllll}
\hline Variable & Coefficient & Std. Error & t-Statistic & Prob. \\
\hline FD & 0.001698 & 0.000802 & 2.116115 & 0.0420 \\
LR & -0.001976 & 0.006177 & -0.319869 & 0.7511 \\
RGDP & $-1.23 \mathrm{E}-05$ & $4.75 \mathrm{E}-05$ & -0.259678 & 0.7967 \\
DUM & 0.016231 & 0.139796 & 0.116104 & 0.9083 \\
C & 0.174814 & 0.248049 & 0.704758 & 0.4859 \\
R-squared & 0.377766 & Mean dependent var & & -0.238342 \\
Adjusted R-squared & 0.302344 & S.D. dependent var & & 0.387294 \\
S.E. of regression & 0.323490 & Sum squared resid & & 3.453318 \\
Long-run variance & 0.101654 & & & \\
\hline
\end{tabular}

Source: EVIEWS Ouptut

Results from the estimated model specify that the coefficients of real income and interest rate are inconsistent with a-priori expectations and insignificant at all conventional levels. However, the coefficient of fiscal deficit is consistent with the a-priori expectation and significant at the five percent level. This is an indication that the twin deficit hypothesis holds for Sierra Leone. Moreover, the confirmation of the hypothesis is in itself is an indication of market failure, underscored by the fact that when government policies fail to engender a well-functioning market system, the resultant effect is market failure (Jackson and Jabbie, 2019). This is because governments' interventions result in no positive outcome to economic recovery, particularly in areas relating to real sector growth as indicated in the country's slow growth rate, which in effect bring about inefficiencies in terms of the net benefits to society, thus leading to government failure (Winston, 2006). The government/ fiscal sector is the fulcrum of the economy.

Hence, problems emanating from the fiscal sector can cause serious macroeconomic distortions, with likely spillages to other sectors (WAMI Occasional Paper, 2013: 44). 
Successive governments in Sierra Leone have been running fiscal deficit for decades. This became very prominent in the latter part of 2016, with tighter budget control as part of the then regime's austerity measure. This attested weaknesses in the country's resource mobilization, which up till the present is incapable of financing current expenditure, despite efforts by the incumbent 2018 government to rationalise spending. This normally instigates the need to borrow from both domestic and external sources in order to finance its spending. However, government spending in entirety can be viewed as a necessary evil, where the ultimate goal is to stimulate growth - it can be considered problematic when resources are unproductively utilised, thereby resulting in negative growth, and to make matters worse, with the resultant effect of debt accumulation, which is normally sourced through financial market window like T-Bills for example, supposedly seen as a crowding-out route for private sector investment and growth in the real sector economy. The occurrence of this situation can be attributed to government failure, which in the strictest sense of the word is consistent with market failure, since the irresponsible action of government policies distort prices and market mechanism.

In the context of Sierra Leone, the cheapest means for government to borrow is through the domestic market by issuing securities (like T-Bills) to commercial banks at attractive interest rates - given that government securities are risk-free, commercial banks are more inclined to lend to the government than dealing with risky 'private entities' ${ }^{3}$, thus resulting in a crowding-out of the private sector - through lack of access to competitive open market financing in support of productive real sector activities. This then results in both internal (by disrupting production, exports, and fueling price pressures) and external imbalances (leading to trade and current account deficits). In addition, the incidence of persistent fiscal deficit is highly precipitated by a continued fiscal dominance of monetary policy (see Warburton and Jackson, forthcoming), wherein the Bank of Sierra Leone's financing of the deficit has taken centre stage in recent time, a situation that partly renders monetary policy ineffective. These developments all attest to the government's inefficiency in managing the economy, which is akin to government failure in terms of policy direction, and by extension market failure.

To confirm whether fiscal deficit is significant in influencing movement in the current account deficit, the coefficient of fiscal deficit (FD) was restricted to zero. This was done mainly to inform cogent inference of fiscal deficit impact on the current account position.

\footnotetext{
3 In the recent past, commercial banks in Sierra Leone diverted their attention away from dealing with private sector investors, particularly when it comes to meeting their requests for loans, which is partly due to their high risks of non-repayment. This in part can be explained by the high perpetration of political interference in meddling with bank intermediation processes and micro-management of state-owned banks in particularly, which resulted in the deteriorating of banks' portfolios and their reduced appetite in dealing with private and even politically exposed individuals.
} 
The probability values of the t-statistic, F-statistic and Chi-square were all significant at the five percent level, reflecting that the null hypothesis of the cointegrating regressor coefficient of FD being zero, was rejected. The linear restriction type of Wald test (see Table 5), both t-test and Chi-square test statistics clearly depicted that fiscal deficit is significant in impacting current account deficit Sierra Leone.

Table 5: Wald Test (LREER) - DOLS

\begin{tabular}{llcl}
\hline Test Statistic & Value & Df & Probability \\
\hline t-statistic & 2.116115 & 33 & 0.0420 \\
F-statistic & 4.477944 & $(1,33)$ & 0.0420 \\
Chi-square & 4.477944 & 1 & 0.0343 \\
\hline
\end{tabular}

Source: EVIEWS Output

\section{Conclusion and Policy Recommendations}

\subsection{Concluding points}

This study is focused on addressing the twin deficit hypothesis, which is a typical case of government failure in the Sierra Leone economy, through utilisation of relevant macroeconomic variables to empirically measure the assertion around the stated objectives and hypothetical statements. In connection with discourses spanning the notion of market failure and trends in government failed administration of public finances and structural problems inherent in the domestic economy (with reference to Figure 1), the story manifested a positive relationship between $\mathrm{CAB}$ and $\mathrm{FD}$, which to some extent signaled successive government failure in effecting policies geared towards efficient management of the economy.

In addition, outcomes from both the correlation and granger causality tests show a strong relationship and a unidirectional causation between $\mathrm{FD}$ and $\mathrm{CAB}$, which warranted further investigation through a co-integration regression. The rationale for this venture is to proffer ways and means by which relevant policy recommendations can be judiciously utilised in addressing the legacy of failed government policies, which present and future leaders can build upon in effectively managing resources geared towards improving the well-being of Sierra Leoneans.

Digressing further and also linked to the identified hypothetical statements and objectives, the real test of the assertion of twin deficits linked to successive government failure in Sierra Leone was further proved through the FMOLS regression model, which shows that the persistence of fiscal deficit is a deterrent to sustaining a current account balance position. This further clarifies that persistent fiscal deficit is akin to government failure and ultimately market failure, given its ripple effect into other sectors of the economy 
- an attestation of the twin deficit hypothesis. As already highlighted in the findings, possible explanations can be attributed to poor governance of natural resources in consonant with persistent disequilibrium in the Balance of Payment [BoP] account. Equally, the fact that successive governments over the years have developed a strong appetite for borrowing (that does not necessary translate into improvement in productive capacity), particularly in recent times, domestic borrowing accessed through the 365 Treasury Bills [T-Bills] window has crowded-out potential for private sector growth. During this period, commercial banks are seen to be hedging their risks in high interests and risk-free T-Bills market, while at the same time manipulating lending rates on the high-end. The story speaks to the fact that proceeds from real sector activities and export earnings have not matched expenditure on import bills - such activities are perceived as the backbone of economic growth, which supports employment and real business activities, and upon which the government can also leverage, through different forms of revenues, for example, income taxes [PAYE], Goods and Services Tax [GST], etc.

\subsection{Suggested Recommendations}

In view of the summarized conclusion for this research paper, the researchers have considered it worthwhile to highlight some recommendations, which can be utilised by those in governance to address issues surrounding the twin deficits crisis that has been a curse story for decades in Sierra Leone:

- In view of the current regime's approach to implementing the Treasury Single Account [TSA], those assigned responsibility of its management should continue to utilise revenues for good causes. Through this, the government will also be better positioned to monitor revenue sources and expenditures, which also make it possible to engineer much needed austerity measures as a way of combatting the country's long history of fiscal indiscipline that went unchecked for nearly two decades. With effective auditing processes set in place, it is possible for resources to be scaled up or down, usually earmarked for utilisation by 'Ministries, Departments and Agencies [MDA]', while also factoring clawback in the event of resource under-utilization.

- The government must continue its drive to facilitate investment promotion geared towards boosting productive real sector operations, while also diversifying economic activities. The reward for such operational effort can be seen through improvement in the rate of employment, 'improvement in productivity', and higher tax returns to government (from

\footnotetext{
4 Improving the level of productivity also supports the central bank in building its foreign reserves, which can also be utilised in importers request for the payments of import bills. Continued mismatch in demand and supply for foreign currencies normally exacerbates the scope for higher level domestic prices and currency devaluation.
} 
PAYE, self-employment and business taxes). This will also help to reduce pressure on the part of government to curb its borrowing appetite from the financial market window - for example T-Bill, which seem to have crowded-out private sector access to loans from commercial banks. Equally, efforts by the government to support investment and growth should also work in line with the BSL's effort to monitor price dynamics, normally channelled through its operational instruments like money supply and the Monetary Policy Rate.

- The government should also pursue varied avenues to establish links with its diaspora communities in developed economies and other parts of the world, in a bid to support the country's drive in boosting foreign reserves. On this note, institutions like the BSL can leverage on its revised 2019 Act, which gives power for the establishment of agents in and outside of the country - this approach can be modelled similarly to that of Ghana, which resulted in the creation of the 'Ghana International Bank' as a way of monitoring the flow of foreign currency transactions. Sierra Leoneans residing outside the country would be very much inclined to deal with credible institution(s) - hence, easing the transaction bottleneck, rather than dealing with not so much credible individuals or institutions, given diaspora experiences connected with scammed transactions (Chunda, 2018). Such exploration can cultivate a myriad of benefits in curbing foreign exchange crisis - a perceived expectation by economic agents in the domestic economy. This will also pave the way for stabilising the deficit in both the fiscal and current accounts.

Peer-review: Externally peer-reviewed.

Conflict of Interest: The authors have no conflict of interest to declare.

Grant Support: The authors declared that this study has received no financial support.

Acknowledgements: The authors wish to express appreciation to colleagues for their efforts in commenting on areas of interest to the paper, particularly with regard to issues on government and market failures. There is no grant attached to the pursuance of this paper; the passion is rooted from the authors' effort to empirically address issues of concern (viz-a-viz government failure in relation to the situation of twin deficit), which was covered in their book chapter contribution - part of the Encyclopedia of Sustainable Development book Series.

\section{References}

Abell, J. (1990), Twin deficits during the 1980s: An empirical investigation, Journal of Macroeconomics, Vol. 12, 81-96.

Bangura, A., Tarawalie, A.B., Fofanah, L., \& Macarthy, S. (2016). Macroeconomic determinants of budget deficit: Evidence from Sierra Leone. International Journal of Economic Perspectives, Vol. 10(1), 5-13

Barro, R. (1989). The Ricardian approach to budget deficits”, Journal of Economic Perspectives, 3(2), 37-52.

Cavallo, M. (2005). Understanding the twin deficits: New approaches, new results. Federal Reserve Bank of San Francisco Economic Letter, No. 16.

Chowdhary, K. and Saleh, A. S. (2007). Testing the Keynesian proposition of twin deficits in the presence of trade liberalization: Evidence from Sri Lanka. Economics Working Papers. 
Chunda, S.M. (2018). Diaspora businesses in Africa: Survival and sustainability. In, Hack-Polay, D., and Siwale, J. (Eds.) African Diaspora Direct Investment. Palgrave Macmillan, Cham. doi: 10.1007/978-3-319-72047-0_8.

Conteh, P.S. (2016). The Credibility of Government Budget: The Case of Sierra Leone. PhD Thesis, University of Walden USA.

Cunningham, S. (2011). Understanding market failures in an economic development context. Mesopartner Monograph 4: Pretoria, South Africa.

Darrat, A. F. (1988). Have large budget deficits caused rising trade deficit? Southern Economics Journal, 54, 879-887.

Dudley, William C. \& McKelvey, E. F. (2004). The US budget outlook: a surplus of deficits. Global Economic Paper 106, Goldman Sachs, New York.

Epaphra, M. (2017). The twin deficits hypothesis: an empirical analysis for Tanzania. The Romanian Economic Journal, Vol. 20(65), 2-34.

Fleming, M. J. (1962). Domestic financial policies under fixed and floating exchange rates, IMF Staff Papers 9 , 369-379.

Haug, A. A. (1996). Blanchard's model of consumption: An empirical study. Journal of Business \& Economic Statistics, 14(2), 169-177. doi: 0.2307/1392428.

Jackson, E.A. (forthcoming). Hermeneutics of Ceteris Paribus in the African Context.

Jackson, E.A. (2019). Systemic health care failure as a symptom of market failure in Sierra Leone. South African Journal of Public Health, 3(4), 72-78. doi: 10.7196/SHS.2019.v3.i4.100.

Jackson, E.A. and Jabbie, M. (2019). Understanding market failure in the developing country context. In, Walter L. Filho (eds), Decent Work and Economic Growth: Encyclopedia of Sustainable Development Goals (Online First). Springer Nature, Cham. doi: 10.1007/978-3-319-71058-7_44-1.

Jackson, E. A. (2017). Economic methodology: paradox of ceteris paribus (cp) law in the context of Sierra Leone. Method(e)s: African Review of Social Sciences Methodology, 2(1-2), 31-40. doi: 10.1080/23754745. 2017.1354553 .

Jackson, E.A. (2016). Phronesis and resource curse hypothesis in post-independent Sierra Leone. Ilorin Journal of Economic Policy, 3(1), 1-10.

Jackson, E.A., Jabbie, M. and Tamuke, E. (forthcoming). Dynamic effect of inflation shocks in Sierra Leone: An empirical analysis (2007M01 - 2019M03).

Jones, Y.M. (2014). Debt overhand and natural resources: Revisiting the resource curse hypothesis. PhD Thesis, Birkbeck College, University of London.

Kearney, C. and Monadjemi, M. (1990). Fiscal policy and current account performance: international evidence on the twin deficits. Journal of Macroeconomics, 12(2), 197-219. doi: 10.1016/0164-0704(90)90029-A.

Kılınç, M., Tunç C. \& Yörükoğlu, M. (2014). Twin stability problem: Joint issues of high current account deficit and high inflation. Central Bank of the Republic of Turkey, BIS Working Paper No. 89. Retrieved from: https:// www.bis.org/publ/bppdf/bispap89z.pdf.

Kim, S. and Roubini, N. (2008). Twin deficit or twin divergence? fiscal policy, current account and real exchange rate in the U.S. Journal of International Economics, 74, 362-383.

Korsu, R.D. (2014). The inflationary effects of fiscal deficit in Sierra Leone: A simulation approach. African Economic Research Consortium (AERC), Research Paper No. 290.

Lau, E. and Baharumshah, A. Z. (2006). Twin deficits hypothesis in SEACEN Countries: A panel data analysis of relationships between public budget and current account deficits. Applied Econometrics and International Development, 6(2), 213-226.

Maddala G. S. \& Kim I.M. (1998). Unit Root, Cointegration and Structural Change. 1st ed. New York: Cambridge University Press. 
Messner, D. \& Meyer-Stamer, J. 1992. Recipe for success: strong state and strong enterprises. Development and Cooperation, 2.

Mundell, R. A. (1963). Capital mobility and stabilization policy under fixed and flexible exchange rates. Canadian Journal of Economics and Political Science, 29, 475-85.

Olanipekun, D. B. (2012). A bound testing analysis of budget deficits and current account balance in Nigeria 19602008. International Business Management, 6(4), 408-416.

Sakyi, D. \& Opoku, E.E.O. (2016). The twin deficits hypothesis in developing countries: Empirical evidence for Ghana. Working Paper, International Growth Centre (IGC). Retrieved from: https://www.theigc.org/wpcontent/uploads/2016/09/Sakyi-Opoku-2016-working-paper.pdf.

Suresh, K.G. and Tiwari, A. K. (2014). A Structural VAR (SVAR) analysis of fiscal shocks on current accounts in India. Macroeconomics and Finance in Emerging Market Economies, 7(1), 140-153.

Tarawalie, A.B. (2014). Fiscal deficits and current account imbalances: Evidence from Sierra Leone. International of Business and Social Studies, 5(8), 256-269.

Thomas, R.A. (2018). IMF confirms suspension of funding as APC government fails to generate revenue. Retrieved from: https:/www.thesierraleonetelegraph.com/imf-confirms-suspension-of-funding-as-apc-government-failsto-generate-revenue/.

Toda, H.Y. \& T. Yamamoto, 1995. Statistical inference in vector auto-regressions with possibly integrated process. Journal of Economics, 66, 225-250.

Uz, I. (2010). Determinants of Current Account: The relationship between internal and external balances in Turkey. Applied Econometrics and International Development, 10(2), 115-126.

United Nations. (2011). About Sierra Leone. Retrieved from: https: www.sl.undp.org/content/sierraleone/en/home/ countryinfo/.

Vyshnyak, O. (2000). Twin deficit hypothesis: the case of Ukraine. Master's Thesis, National University of Kyiv Mohyla Academy.

WAMI Occasional Paper. (2013). Fiscal and monetary policy coordination in the WAMZ: implications for member states' performance on the convergence criteria, 1(4), 1-4.

Warburton, C.E.S. and Jackson, E.A. (forthcoming). Monetary policy responses to exogenous perturbations: the case of a small open economy (2007-2018).

Warburton, C.E.S., (2013). When markets fail: asset price, government expenditures, and the velocity of money. Applied Econometrics and International Development, Euro-American Association of Economic Development, 13(2), 73-92.

Winston, C. (2006). Government failure versus market failure: macroeconomics policy research and government performance. AEI-Brookings Joint Center for Regulatory Studies, the American Enterprise Institute for Public Policy Research, Brookings Institution, Washington, D.C.

World Bank. (2018). Reviving Urban Development: the importance of freetown for the national economy. Sierra Leone Economic Update, Edition No. 1. Retrieved from: http://documents.worldbank.org/curated/ en/304841528737912303/pdf/127049-WP-PUBLIC-SierraLeoneEconomicUpdatev.pdf.

Zayid, J. (2018). Sierra Leone - African Economic Outlook. Retrieved from: https://www.afdb.org/fileadmin/ uploads/afdb/Documents/Generic-Documents/country_notes/Sierra_Leone_country_note.pdf. 


\section{Appendices}

APPENDIX 1A: CORRELATION MATRIX RESULT

\begin{tabular}{lllll}
\hline & CAB & FD & LR & RGDP \\
\hline CAB & 1.000000 & 0.614892 & 0.229691 & -0.511559 \\
FD & 0.614892 & 1.000000 & 0.451304 & -0.734817 \\
LR & 0.229691 & 0.451304 & 1.000000 & -0.225738 \\
RGDP & -0.511559 & -0.734817 & -0.225738 & 1.000000 \\
\hline
\end{tabular}

Source: EVIEWS Output

\section{APPENDIX 1B: PAIRWISE GRANGER CAUSALITY TESTS}

\begin{tabular}{llll}
\hline $\begin{array}{l}\text { Sample: } 1980-2018 \\
\text { Lags: } 1\end{array}$ & Obs & F-Statistic & Prob. \\
\hline Null Hypothesis: & 38 & 3.14314 & 0.0850 \\
\hline FD does not Granger Cause CAB & & 1.76434 & 0.1927 \\
CAB does not Granger Cause FD & 38 & 0.21536 & 0.6455 \\
& & 0.76459 & 0.3879 \\
LR does not Granger Cause CAB & & & \\
CAB does not Granger Cause LR & 38 & 0.86560 & 0.3585 \\
& & 11.1302 & 0.0020 \\
RGDP does not Granger Cause CAB & 38 & & 0.08157 \\
CAB does not Granger Cause RGDP & & 2.00461 & 0.7769 \\
& 38 & & 0.1657 \\
LR does not Granger Cause FD & & 1.85977 & 0.1814 \\
FD does not Granger Cause LR & 38 & 4.84634 & 0.0344 \\
RGDP does not Granger Cause FD & & 0.00920 & 0.9241 \\
FD does not Granger Cause RGDP & & 1.65887 & 0.2062 \\
\hline RGDP does not Granger Cause LR & & & \\
LR does not Granger Cause RGDP & & & \\
\hline
\end{tabular}

Source: EVIEWS Output 